AN INFORMAL REPORT

Source Term Calculations for Pioneer

Radioisotopic Thermoelectric Genurators

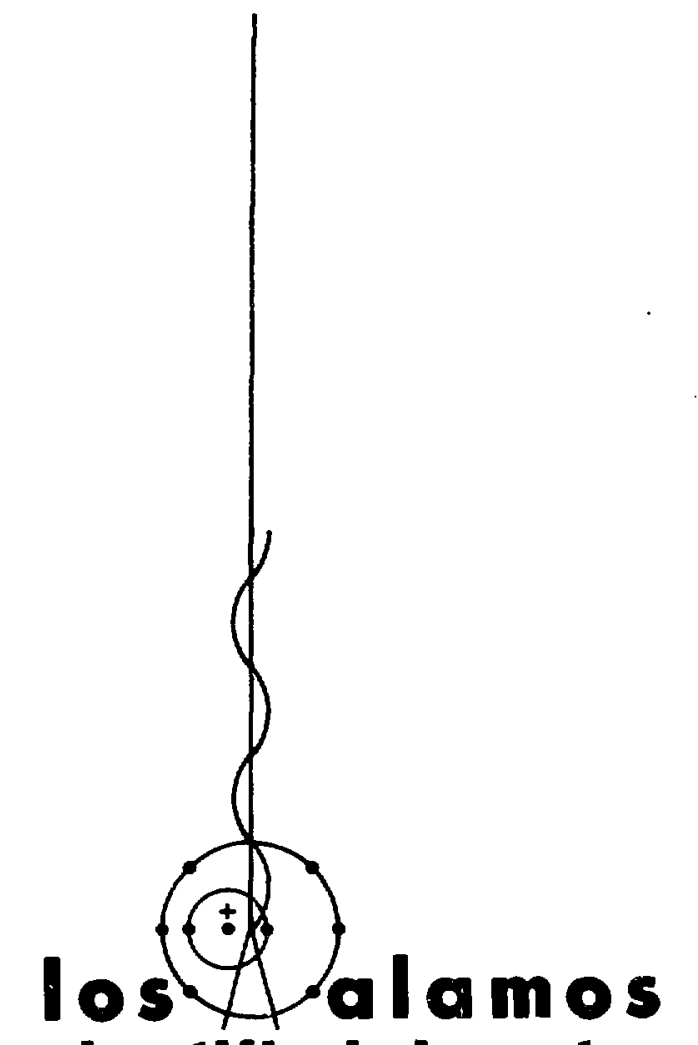

\title{
scieniffic laboratory
}

of the University of California

LOS ALAMOS, NEW MEXICO 87544

1

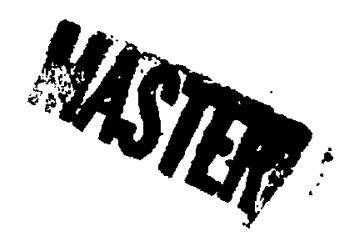


This report was prepared as an account of work sporisored by the United States Government. Neither the United States nor the United States Atomic Energy Commission, nor any of their employees, nor any of their contractors, subcontractors, or their employees, makes any warranty, express or implied, or assumes any legal liability or responsibility for the accuracy, completeness or usefulness of any information, apparatus, product or process disclosed, or represents that its use would not infringe privately owned rights.

In the interest of prompt distribution, this LAMS report was not edited by the Technical information staff.

Printed in the United States of America. Available from

National Technical Information Service

U. S. Department of Commerce

5285 Port Royal Road

Springfield, Virginia 22151

Price: Printed Copy \$3.00; Microfiche \$0.95 


\title{
Source Term Calculations for Pioneer
}

\section{Radioisotopic Thermoelectric Generators}

\author{
by
}

S. E. Bronisz

This work performed under the auspices of the U. S. Atomic Energy Commission and the Space Nuclear Sy'stems Office.

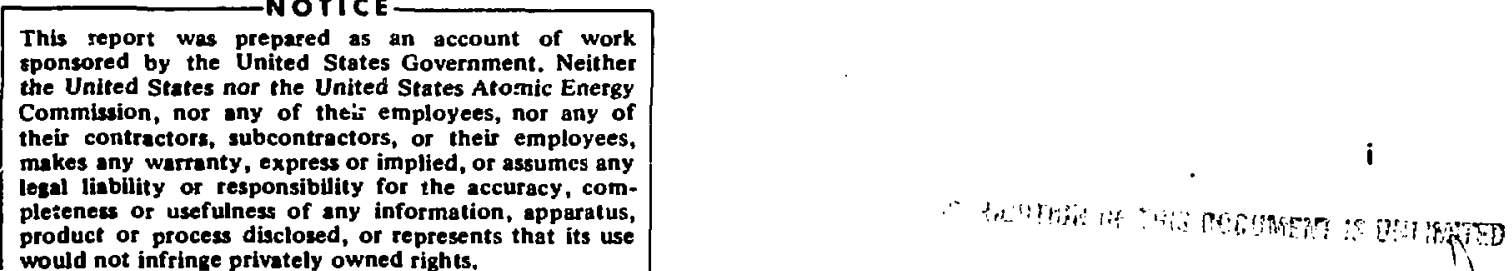




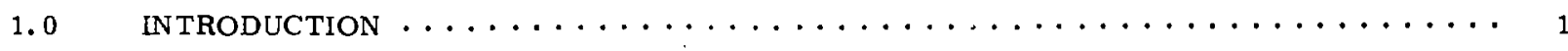

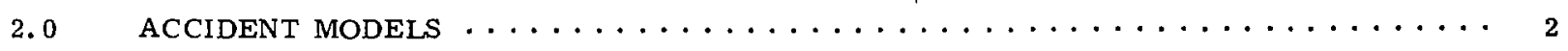

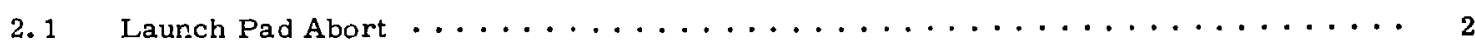

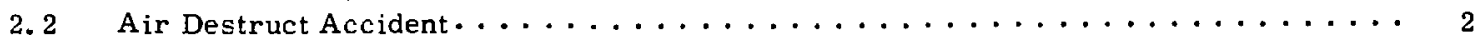

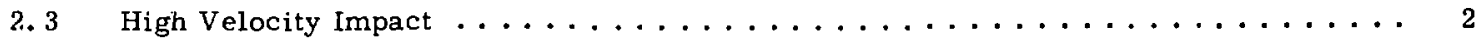

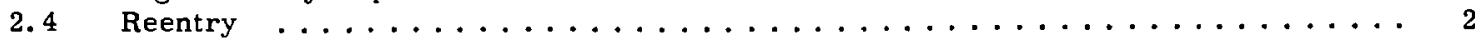

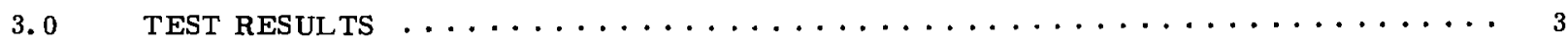

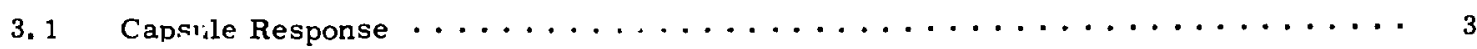

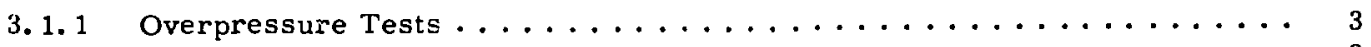

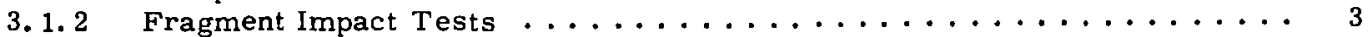

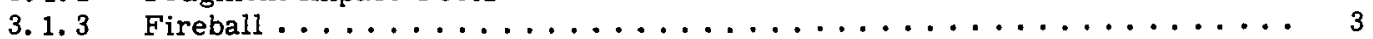

3. 1.4 Residual Propellant Fires ......................... 3

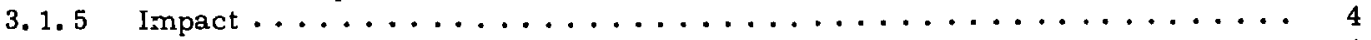

3.1 .6 Post-impact Oxidation ......................... 4

3.2 Capsule Condition $\ldots \ldots \ldots \ldots \ldots$

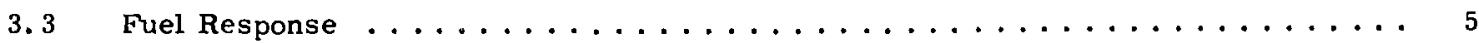

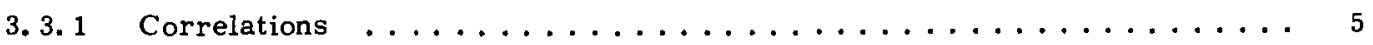

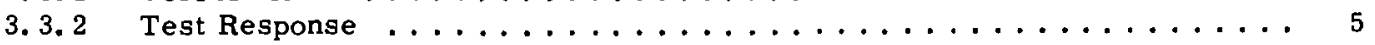

3. 3.2.1 vibration .......................... 5

3. 3.2.2 Overpressure and Fragment Impact ................ 5

3. 3.2.3 Impact ............................. 6

3.3.2.4 Post-impact Oxidation 9

$4.0 \quad$ FUEL RELEASE ASSUMPTIONS $\ldots \ldots \ldots \ldots$

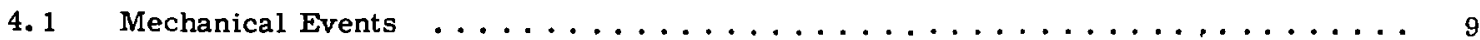

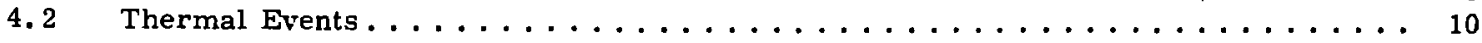

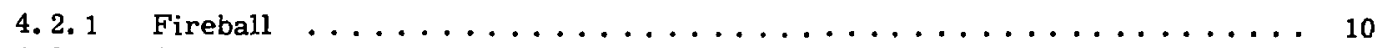

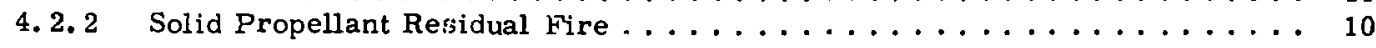

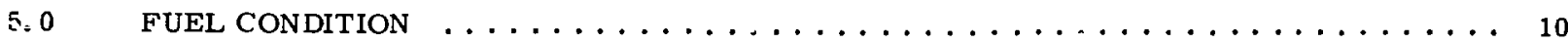

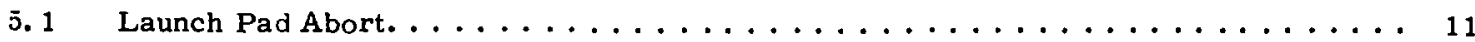

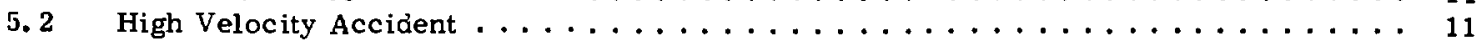

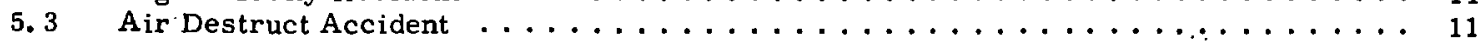

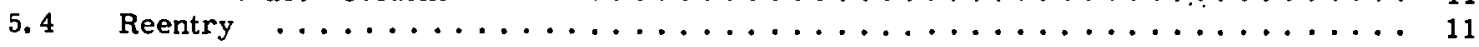

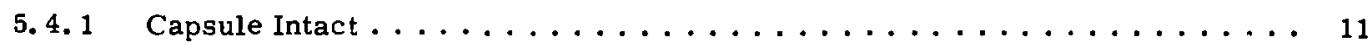

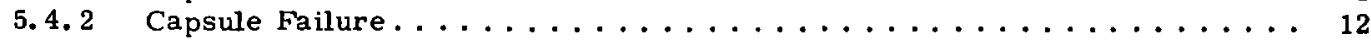

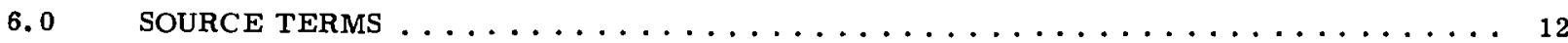

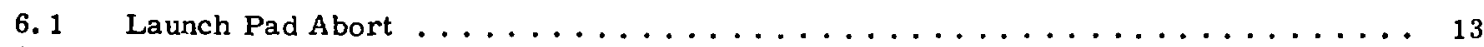

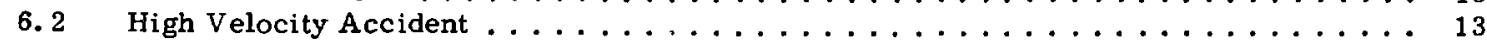

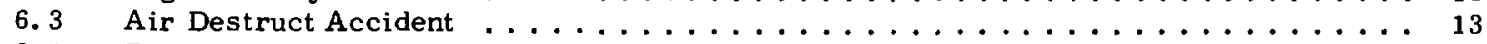

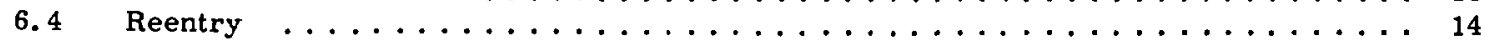

6.4 .1 Capsule Intact .............................. 14

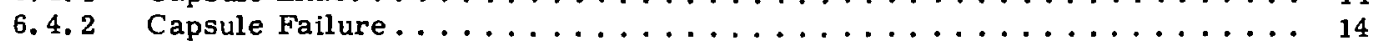

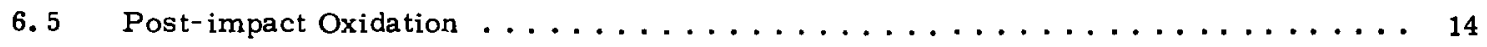

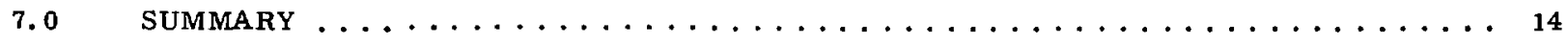




\section{LIST OF TABLES}

Table No. Caption

$3.1 \ldots . .$. PMC/SSCS impact tines correlation factors, $s 4 \mu \mathrm{m} \ldots \ldots \ldots$

$3.2 \ldots$ Particle size distribution, Pioneer capsule P-23 ................

$3.3 \ldots$ Sub-sieve size particle distribution, Pioneer capsule P-23 ............. 6

$3.4 \ldots$ Particle size distribution, Pioneer capsule P-24 ................ 6

$3.5 \ldots$ Sub-sieve size particle distribution, Pioneer capsule P-24 ............. 6

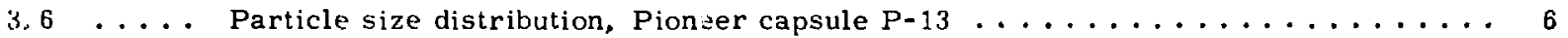

$3.7 \ldots$ Sub-sieve size particle distribution, Pioneer capsule P-13 ............

$3.8 \ldots$ Particle size distribution, Pioneer capsule P-10 .................. . .

3. ..... Sub-sieve size particle distribution, Pioneer capsule P-10 ............

$3.10 \ldots$ Particle size distribution, Transit capsule T-35 ................

3.11 .... Sub-sieve size particle distribution, Transit capsule T-35 ..... . . . . . 8

$3.12 \ldots$... Calculated particle size distribution for an end-on Pioneer capsule impact on

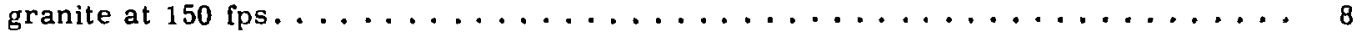

3.13 ... Calculated sub-sieve size particle distribution for an end-on Pioneer capsule

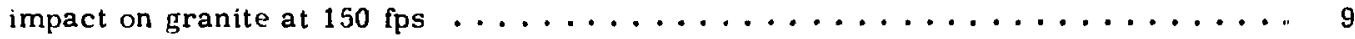

$3.14 \ldots$... Calculated particle size distribution for bare PMC impacted on a hard surface

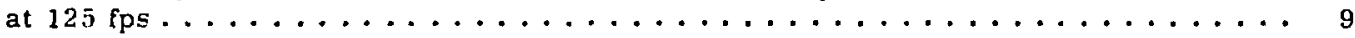

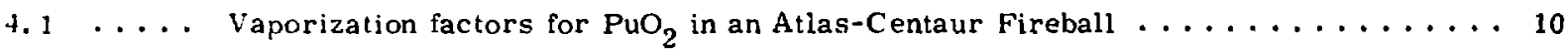

$5.1 \ldots \ldots$ Fuel size distribution - Launch pad abort .....................11

$5.2 \ldots \ldots$ Fuel size distribution $-\ldots$ High velocity accident $\ldots \ldots \ldots \ldots$

$5.3 \ldots \ldots$ Fuel size distribution $\ldots$ Air destruct accident $\ldots \ldots \ldots$

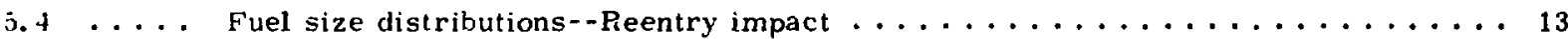

T. 1 .... Source term summary for a Pioneer RTG exposed to accident

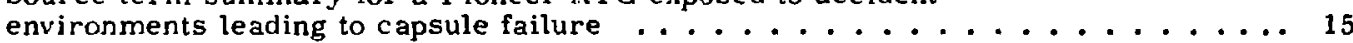

\section{LIST OF FIGURES}

\section{Figure No.}

5. 1 .... Fuel size distribution, launch pad abort accident

5. 2 ... Fuel size distributions, high velocity impact accident

Ђ. $3 \ldots \ldots$ Fuel size distributions, air destruct accideni $\ldots \ldots \ldots \ldots$ 
SOURCE TERM CALCULATIONS FOR

PIONEER RADIOISOTOPIC THERMOELECTRIC GENERATORS

by

S. E. Bronisz

ABSTRACT

Quantities of radioactive material that would be expected to be released as the result of the exposure of a Pioneer radioisotopic thermoelectric generator to certain accident environmerits have been calculated. The conventions used in these calculations are described in detail, as are the reasons for choosing the conventions. The final source terms are believed to be safety conservative, but the actual degree of conservatism cannot be determined.

\section{0 INTRODUCTION}

The evaluation of risks involved in using nuclear systems for space missions requires that the possible release of radioactive materials, the source term, to the biosphere be defined for each possible accident environment. The purpose of this report is to present the methods by which such source terms were calculated for accidents involving the nuclear power systems to be used in generating electrical power on the Pioneer spacecraft.

The Pioneer spacecraft is an interplanetary probe designed to fly past Jupiter and to examine interplanetary space. Power for the various experiments aboard the spacecraft will be provided by four radioisotopic thermoelectric generators (RTG's), each containing about $20,200 \mathrm{Ci}$ of ${ }^{238} \mathrm{Pu}$ as plutonium dioxide combined with 17.5 vol $\%$ molybdenum in the form of cermet disks (PMC) contained within a metallic capsule. The capsule, in turn, is contained within a graphite heat shield. The fuel/capsule/heat shield assembly, i. e. the heat source, is surrounded by thermoelectric elements and is contained with them in a gas-tight magnesium alloy housing. (1)

The heat source capsule is a cylinder with hemispherical ends made in four layers; an inner liner, a liner, a strength member, and an outer clad. The inner liner is Mo-46 wt \% Re, 0.005 in. thick, and impedes interaction between the $\mathrm{PuO}_{2}$ in the fuel and the tantalum components in the capsule. It is formed from three pieces, two hemispherical ends and a cylindrical body, by spot welding and has no structural effect on the capsule. The liner is Ta-20 wt\% W, 0.02 in. thick, with a pressure relief device in one end. It is assembled by welding two pieces, a hemispherical cap and a cylindrical body with a hemispherical end, and is gas tight, except for the PRD which allows escape of the helium evolved from the decay of ${ }^{238} \mathrm{Pu}$. The liner serves as a contamination barrier in the assembly operation. The third layer, the 
strength member, is a 0.09-in. thick Ta-8 wt \% W2 wt \% Hf alloy (T-111) shell designed to provide the primary mechanical protection. It, too, is assembled from two pieces by welding. The cap has two small holes to allow helium to escape. The outer layer, the clad, is made, again in two pieces, from 0.02 in. - thick $\mathrm{Pt}-20 \mathrm{wt} \% \mathrm{Rh}$. It has one small hole in the body end for helium release.

The responses of the heat source capsule and the fuel to thermal and mechanical environments representative of accident conditions were determined experimentally through use of capsules loaded with a fuel simulant. The results of the experiments were then used to predict the expected behavior of actual heat source capsules in possible accident environments.

No attempt is made here to integrate the source term calcuiations with the probability of occurrence of the environment responsible for the source term. This has been done in the Pioneer $F$ Safety Evaluation Report. (2)

\section{0 ACCIDENT MODELS}

Four general accident cases were considered: launch pad abort, air destruct, high velocity impact, and reentry impact. Each accident case includes a series of environments, present at various times during the accident, which are described below.

\section{1 Launch Pad Abort}

The basic assumption for this type of accident is that the liquid-fueled Atlas-Centaur launch vehicle explodes at the approximate time of launch resulting in exposure of the capsule to one or more of the following environments: blast overpressure, impact of fragments, fireball, impact on the ground at $\sim 150 \mathrm{fps}$, and residual propellant fires. Except for the case of exposure to residual fires, the capsule temperature would be $\sim 1500^{\circ} \mathrm{F}$. The effects of the environments on a capsule and the total number of environments affecting the capsule depend on the stage of the accident at which the capsule is separated from the RTG. The source terms presentedbelow are based on the assumption that the capsule is exposed by the blast overpressure, but they are described in such a way that results of exposure at any later stage of the accident can be calculated.

\section{Air Destruct Accident}

This accident case would occur if the launch vehicle were to go off course sufficiently to warrant its destruction, as a protective measure, by the Range Safety Officer. Such an accident might expose the capsule to blast overpressure, fragment impact, fireball, ground impact at $\sim 325 \mathrm{fps}$, and / or residual propellant fires. Again the assumption is that the blast-overpressure would expose the capsule. The capsule would be a temperature of $\sim 1500^{\circ} \mathrm{F}$, except when exposed to a residual fire.

\section{3 High Velocity Impact}

This accident would occur if a launch vehicle malfunction resulted in a $180^{\circ}$ change in direction of the vehicle and a poweled impact into the launch area without successful destruction action. As a result of such an accident, a heat source capsule might be exposed to impact, blast overpressure, fragment impact, fireball, and/or residual propellant fires. The impact velocity of the vehicle would be $\sim 550 \mathrm{fps}$, but the capsule itself would have a iower impact velocity because of the mitigating, effects of the generator, the spacecraft, and the rocket shrouds.

\subsection{Reentry}

In the event that the spacecraft should fail to reach escape velocity it would reenter the atmosphere. The heat of reentry would release the heat source from the generator and allow it to impact the earth. Thus, the capsule would be exposed to reentry heating (in the graphite heat shield), earth impact, and post impact oxidation. If the graphite heat shield were to fail, the unp rotected capsule could fail in reentry and expose the bare fuel disks to the reentry and impact conditions. The impact velocity of an intact heat source would be $\sim 300 \mathrm{fps}$ 
and that of released disks would be $\sim 125 \mathrm{fps}$.

\subsection{TEST RESULTS}

The Pioneer heat source capsule was subjected to a series of tests designed to simulate environments thought to be representative of those attributed to the various possible accidents. The test series was designed by Teledyne Isotopes, the RTG contractor, and was carried out by personnel of Sandia Ccrporation. After being tested the capsules were examined at LASL to determine the response of the capsules and the fuel simulant to the tests. Details of the tests and the results are included in the test report documents published by Teledyne Isotopes. (3)

In addition to the capsule tests, a series of bare fuel impact tests was run to determine the correlation between the break-up characteristics of the fuel and its simulant. These tests were racessary because ic was not practicable to test fueled capsules.

\section{1 Capsule Response}

The capsules used in the safety evaluation tests did not contain the 0.005-in. Mo-Re inner liner. The assumption has been made that the inner liner would not sigrific antly affect the mechanical response of the capsule.

3.1.1 Overpressure Tests. Two capsules, each contained in a generator, were exposed to overpressures of $320 \mathrm{psig}$ at $1.95 \mathrm{psig}-\mathrm{sec}$ and 1700 psig at $0,26 \mathrm{psig-sec,} \mathrm{respectively.} \mathrm{In} \mathrm{both} \mathrm{cases,}$ the generator housing and the graphite heat shield assembly were removed by the blast, but the capsule was not breached. In the 320 psig test, the capsule appeared to be unaffected, while in the $1700 \mathrm{psig}$ test the side of the capsule nearest the blast was deformed. The test results indicated that the capsule could withstand at least 1700 psig at 0.26 psig-sec without failing. This overpressure is thought to simulate the actual overpressure of the maximum realistic launch abort explosion. Since the capsule survived these tests, the conclusion is that it would survive all credible overpressures and thus there are no overpressure source terms. Because the capsules were to be used in additionai tests, the fuel response was not determined in the overpressure tests.

\subsubsection{Fragment Impact Tests. Four cap-} sules were subjected to impacts of four different fragments, a 38. 5-1b electronic chassis at 409 fps, a 0.85-1b titanium sheet flat-on at $2100 \mathrm{fps}$, a 0.85lb titanium sheet edge-on at $1700 \mathrm{fps}$, and a 1.28-' 1b titanium sheet edge-on at $495 \mathrm{fps}$. None of these fragments breached the capsule, but all except the flai-on sheet broke the outer cladding. Each of the fragments caused piastic deformation of the capsule and some break-up of the fuel simulant in the capsules.

For the source term analysis, it was assumed that no fragment impact would cause release of the fuel in the launch abort and air destruct accidents. It was further assumed, however, that, in the high velocity impact case, fragments having greater energies might be present and could damage the capsule sufficiently to cause release of fuel. Since no experimental failure was available to use as a basis for predicting the results of such an event, it was assumed that the impact of a high energy fragment would make as large a hole in the strength member as was made in the worst failure experienced in the granite impact test program described below.

\subsubsection{Fireball. No tests to simulate ex-} posure of the capsule to the fireball were made. Comparison of fireball conditions with those of the solid fire tests indicated that, because of the short duration of the firetali and the relatively large heat capacity of the capsule, no serious damage would be caused by the fireball.

3.1. 4 Residual Propellant Fires. Tour capsules were exposed to both liquid and solid propellant fires. The liquid fires caused no additional damage to any capsule and so it was concluted that exposure of a ueled capsule to a liqlid propellant 
fire would not result in capsule damage or fuel release.

In the solid fire tests, the capsule was damaged when not protected by its graphite heat shield. but not damaged when it was in the heat shield. The clad of a bare capsule placed between burning blocks of solid propellant melted and reacted with the strength member, but the capsule was not breached. Two bare capsules placed on a burning block of solid propellant, however, were breached, exposing fuel simulant, during a 4.75-min fire. In both capsules, the breaches were similar in size and location, being elliptical with major and minor axes of $\sim 0.75$ and $\sim 0.5$ in. , respectively, and located in the hemispherical end of each capsule.

3.1.5 Impact. Test capsules were impacted or wnite and hard soil at 300 to $348 \mathrm{fps}$ at $2400^{\circ} \mathrm{F}$ ans a varionitigles. The designated test velocity s. 39 as chosen because it is about 10 percent higher than the terminaj velocity of the capsule. Most of th: capsuies were exposed to a simulated reentry environment $\mathrm{pr}$ ior to impact.

The soil impact caused no capsule failure and only minor capsule deformation, so it was conciuded that no capsule failures would occur in any accident environment involving soil impact.

Thren: out of seven of the capsules that were impacted on flat granite failed. The failure, in each case. consided of a synall crack about 0.06 in. $x$ 0.75 in. extending through all three layers of the test capsule.

One capsule was impacted on chunks of granite, ans iailed through formation of a rough hole hasing an area of $2.5 \mathrm{~cm}^{2}$. The largest sphere that could pass through this hole would be $0.6 \mathrm{~cm}$ dia. In the Transi: program, (4) three capsules nexc impacted on csicrete. None failed, so it $w a s$ concludea that impacits on concrete would release no frel.

On the basis of these results it was assumed that the fueled capsule would fail during a launch abort only if it impacted the sharp edges of the steel launch structure. Also, failure was assumed in the air destruct case or in the high velocity impact case if the capsule inspacted a hard surface.

Finally, failure was assumed if the capsule impacted a hard surface after reentry. In all cases, the extent of the failure was assumed to be equal to that of the largest failure seen, the impact onto rough granite. Such an assumption is conservative in all cases except that of the impact on rough, hard surfaces after reentry, but there seems to be no way of accurately scaling the magnitude of the failures to be expected in the other cases.

3.1.6 Post-impact Oxidation. In the Transit test prowam, impacted capsules still containing the fuel simulant were oxidized using both internal (5) and external (4) electrical heat sources. The results showed that after a few days the tantalum components oxidize, force the clad to split, and expose the fuel to the environment. This result is to be expected, even if the clad were not damaged, because the vent hole in the clad would permit atmospheric oxygen to contact the strength member. 3.2 Capsule Condition

All of the above statements on probable capsule response apply to capsules similar to those used in the test series. In the earlier capsule design, which included no molybdenum-rhenium inner liner, oxygen could migrate from the fuel into the tantalum liner and strength member, rendering them brittle. The addition of the molybdenum-rhenium inner linner apparently has eliminated this problem for the launch accident and prompt reentry accident. $(6,7)$ In the case of the delayed reentry accident, however, it must be assumed that the capsule will be brittle and will behave differently from the test capsules. No data are available to indicate the extent of the difference, but it was assumed that after several months the capsule would have essentially no fuel containment capability under accident conditions. 


\section{3 Fuel Response}

3.3.1 Correlations. It was not possible to determine, directly, the behavior of PMC fueled capsules in the accident environments. Instead, the capsules were filled with a $\mathrm{ThO}_{2}-14$ wt \% Mo fuel simulant. The particle size distribution of the simulant was determined after various tests, thus providing some of the information neressary to calculate source terms. ${ }^{(8)}$

A correlation between the fines distributions of fuel and simulant was determined by impacting small samples of each at $325 \mathrm{fps}$ and $454^{\circ} \mathrm{C}\left(850^{\circ} \mathrm{F}\right)$. The correlation factors are given in Table 3.1. It is assumed that these factors also apply at higher temperatures. For all accident environments the temperature would be at least $815^{\circ} \mathrm{C}\left(1500^{\circ} \mathrm{F}\right)$ Since the melting point of the $\mathrm{ThO}_{2}$ in the SSCS is about $900^{\circ} \mathrm{C}\left(1620^{\circ} \mathrm{F}\right)$ higher than that of the $\mathrm{PuO}_{2}$ in the $P M C$, it is expected that at any temperature the $\mathrm{PuO}_{2}$.would tend to be less brittle than the $\mathrm{ThO}_{2}$ and, thus, the factors are conservative.

For the purpose of simplifying the calculations of the source terms the correlation factor for all launch cases was assumed to be 1.0 , so the particle size data determined from the SSCS in the capsules could be used directly. For the case of delayed orbital reentry the factor was assumed to be 1.5 .

One further assumption, that the quantity of particles fuimed on impact is proportional to the square of the impact velocity. was made. This

TABLE 3.1

PMC/SSCS IMPACT FINES CORRELATION FACTORS, $\leq 4 \mathrm{um}$

\section{PMC Condition}

\section{Fresha}

A ge $\mathrm{d}^{\mathrm{b}}$

Aged and Reentered ${ }^{c}$

Aged, long term ${ }^{\mathrm{d}}$

a No heat treatment after fabrication.

b) 82 days at $815^{\circ} \mathrm{C}$.

c 42 days at $815^{\circ} \mathrm{C}$, followed by a simulated orbital reentry heat pulse.

d 75 days at $1370^{\circ} \mathrm{C}$.
Multiply SSCS Fines By:

0.34
0.83
1.03
1.47
n.

allows the size distribution observed after an impact at one velocity to be corrected to apply to another velocity by multiplying the observed distribution by the quotient of the velocities squared.

\section{3.2 Test Response.}

$$
\text { 3.3.2.1 Vibration. Each RTG is sub- }
$$
jected to a qualification vibration test prior to launch and also to the vibration of the launch itself. Such vibration causes minor fracturing of the edges of the fuel disks, because the fuel does not completely fill the capsule. The amount of break-up to be expected was determined by comparing the particle size distributions of test capsules P-23 and P-24. Each capsule had been exposed to a reentry simulation and an impact at terminal velocity on soil. In addition, capsule $\mathrm{P}-\mathbf{2 3}$ had been subjected to a qualification level vibration test prior to impact, so that the differences between the fuel simulant responses could be used as a measure of the amount of break-up caused by the qualification level vibration test. The P-23 particle size data are given in Tables 3.2 and 3.3 and those of $\mathrm{P}-24$ are given in Tables 3.4 and 3.5 .

\subsubsection{Overpressure and Fragment}

Impact. These two environments were not treated separately in the post-test examinations, but the fuel simulant from capsule P-13, which had been exposed to the 1700 psig overpressure and

TABLE 3.2

\section{PARTICLE SIZE DISTRIBUTION, PIONEER CAPSULE P-23}

Impact velocity: $325 \mathrm{fps}$ Impact angle: $0.0^{\circ}$ Impact temperature: $2400^{\circ} \mathrm{F}$

\begin{tabular}{ccc}
$\begin{array}{c}\text { Screen Size, } \\
\text { Micron }\end{array}$ & $\begin{array}{c}\text { Weight } \\
\text { Fraction }\end{array}$ & $\begin{array}{c}\text { Accumulated Weight } \\
\text { Fraction }\end{array}$ \\
\cline { 1 - 1 } 2000 & 0.99760 & 0.99760 \\
841 & .00016 & .99776 \\
420 & .00017 & .99792 \\
177 & .00016 & .99808 \\
125 & .00008 & .99816 \\
74 & .00016 & .99831 \\
44 & .00025 & .99856 \\
30 & .00022 & .99879 \\
20 & .00027 & .99905 \\
10 & .00040 & .99945 \\
-10 & .00055 & 1.00000
\end{tabular}


TABLE 3.3

SUB-SIEVE SIZE PARTICLE DISTRIBUTION, PIONEER CAPSULE P-23

Impact velocity: 325 fps

Impact temperature: $2400^{\circ} \mathrm{F}$

Maximum Size In

Weight Accumulated

Range. Microns Number Fraction Weight Fraction
0.10
.20
.30
.40
.50
.60
.70
.80
.90
1.00
1.25
1. 50
1. 75
2. 00
2. 25
2. 50
2. 75
3.00
4.00
5.00
6.00
7. 00
8.00
9.00

10. 00
TABLE 3.5

SUB-SIEVE SIZE PARTICLE DISTRIBUTION, PIONEER CAPSULE P-24

Impact velocity: $325 \mathrm{fps}$

Impact temperature: $2400^{\circ} \mathrm{F}$

Maximum Size in

Weight Accumulated

Range, Microns Number Fraction Weight Fraction
0.10
.20
.30
.40
.50
.60
.70
.80
.90
1.00
1.25
1. 50
1.75
2. 00
2. 25
2. 50
2. 75
3.00
4.00
5. 00
6.00
7.00
8.00
9.00
10.00

\subsection{0}

.000000

.000000

.000000

.000000

.000000

.000000

.000000

.000000

.000000

.000000

.000000

.000000

.000000

.000000

.000000

.000000

.000000

.000000

.000000

.000001

.000000

.000001

.000001

.000006
0.000000

.000000

.000000

.000000

.000000

.000000

.000000

.000000

.000000

.000000

.000000

.000000

.000000

.000000

.000000

.000000

.000001

.000001

.000001

.000001

.000002

.000002

.000003

.000004

.000010

the $2100 \mathrm{fps}$ flat sheet fragment impact, was subjected to a particle size analysis. The results are given in Tables 3.6 and 3.7. The size distribution observed was assumed to be characteristic of those for all fragment impacts.

TABLE 3.4

\section{PARTICLE SIZE DISTRIBUTION, PIONEER CAPSULE P-24}

Impact velocity: 325 fps Impact angle: $0.0^{\circ}$ Impact temperature: $2400^{\circ} \mathrm{F}$

\begin{tabular}{rcc}
$\begin{array}{c}\text { Screen Size } \\
\text { Microns }\end{array}$ & $\begin{array}{c}\text { Weight } \\
\text { Fraction }\end{array}$ & $\begin{array}{c}\text { Accumulated Weight } \\
\text { Fraction }\end{array}$ \\
\cline { 2 - 3 } 2000 & 0.99979 & 0.99979 \\
841 & .00008 & .99987 \\
420 & .00003 & .99990 \\
177 & .00001 & .99992 \\
125 & .00001 & .99993 \\
74 & .00001 & .99994 \\
44 & .00001 & .99995 \\
30 & .00001 & .99996 \\
20 & .00001 & .99997 \\
10 & .00002 & .99999 \\
-10 & .00001 & 1.00000
\end{tabular}

\subsubsection{Impact. The extent of fuel}

break-up in the Pioneer capsule is governed by the capsule attitude on impact, velocity, temperature, and the type of impact surface. In the accident cases assumed, two attitudes, two velocities, one

TABLE 3.6

\section{PARTICLE SIZE DISTRIBUTION PIONEER CAPSULE P-13}

Impact velocity: $2100 \mathrm{fps}$ Impact angle: $0.0^{\circ}$ Impact temperature: $1850^{\circ} \mathrm{F}$

\begin{tabular}{c} 
Screen Size, \\
Micron \\
\hline 2000 \\
841 \\
420 \\
177 \\
125 \\
74 \\
44 \\
30 \\
20 \\
10 \\
-10
\end{tabular}

\begin{tabular}{cc}
$\begin{array}{c}\text { Weight } \\
\text { Fraction }\end{array}$ & $\begin{array}{c}\text { Accumulated Weight } \\
\text { Fraction }\end{array}$ \\
\cline { 2 - 2 } .98421 & .98421 \\
.00937 & .99358 \\
.00214 & .99572 \\
.00144 & .99716 \\
.00038 & .99754 \\
.00053 & .99807 \\
.00058 & .99865 \\
.00030 & .99895 \\
.00030 & .99925 \\
.00034 & .99960 \\
.00040 & 1.00000
\end{tabular}


TABLE 3.7

SUB-SIEVE SIZE PARTICLE DISTRIBUTION, PIONEER CAPSLLE P-13

Impact velocity: $2100 \mathrm{fps}$

Impact temperature: $1850^{\circ} \mathrm{F}$

\begin{tabular}{rrrr}
$\begin{array}{c}\text { Maximum Size in } \\
\text { Range, Microns }\end{array}$ & Number & $\begin{array}{l}\text { Weight } \\
\text { Fraction }\end{array}$ & $\begin{array}{c}\text { Accumulated } \\
\text { Weight Fraction }\end{array}$ \\
\hline 0.10 & 494 & 0.000000 & 0.000000 \\
.20 & 267 & .000000 & .000000 \\
.30 & 214 & .000000 & .000000 \\
.40 & 115 & .000000 & .000000 \\
.50 & 107 & .000000 & .000000 \\
.60 & 117 & .000000 & .000000 \\
.70 & 107 & .000000 & .000001 \\
.80 & 79 & .000000 & .000001 \\
.90 & 47 & .000000 & .000001 \\
1.00 & 50 & .000000 & .000002 \\
1.25 & 95 & .000002 & .000003 \\
1.50 & 71 & .000002 & .000005 \\
1.75 & 63 & .000003 & .000008 \\
2.00 & 54 & .000004 & .000012 \\
2.25 & 37 & .000004 & .000015 \\
2.50 & 28 & .000004 & .000019 \\
2.75 & 26 & .000005 & .000024 \\
3.00 & 28 & .000006 & .000030 \\
4.00 & 58 & .000031 & .000062 \\
5.00 & 47 & .000050 & .000111 \\
6.00 & 29 & .000053 & .000164 \\
7.00 & 7 & .000020 & .000184 \\
8.00 & 12 & .000052 & .000236 \\
9.00 & 15 & .000037 & .000273 \\
10.00 & & .000127 & .000400 \\
& & &
\end{tabular}

temperature, and two impact surfaces were considered.

The impact test program identified the endon attitude as being the most damaging to the fuel, while the various drop tests identified the characteristic free fall impact attitude as being nearly side on. For the purpose of calculating source terms, the particle size data from capsule P-10, impacted end on. was used for the launch abort and high velocity impact accidents. These data are given in Tables 3.8 and 3.9 .

For the air destruct and reentry accident cases, the heat source was assumed to be free to fall in its characteristic mode of flat spin. No tests were run in the Pioneer program to identify the fuel response to an impact on a hard surface at this attitude, so the particle size data for a Transit program capsule, T-35, impacted on granite with the capsule axis $22.5^{\circ}$ from the plane of the
TABLE 3.8

PARTICLE SIZE DISTRIBUTION PIONEER CAPSULE P-10

Impact velocity: $325 \mathrm{fps}$ Impact angle: $0.0^{\circ}$ Impact temperature: $2400^{\circ} \mathrm{F}$

\begin{tabular}{l} 
Screen Size, \\
Microns \\
\hline 2000 \\
841 \\
420 \\
177 \\
125 \\
74 \\
44 \\
30 \\
20 \\
10 \\
-10
\end{tabular}

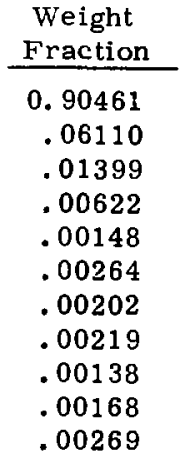

Accumulated Weight

impact surface were used. These data are given in Tables 3,10 and 3.11. The Transit and Pioneer capsules differ only in length. For impact on a relatively soft surface, the particle size data from capsule P-24, Tables 3.4 and 3.5, were used.

TABLE 3.9

SUB-SIEVE SIZE PARTICLE DISTRIBUTION, PIONEER CA PSULE P-10

Impact velocity: $325 \mathrm{fps}$ Impact temperature: $2400^{\circ} \mathrm{F}$

Maximum Size in Weight Accumulated Range, Microns Number Fraction Weight Fraction

$\begin{array}{rrrr}0.10 & 525 & 0.000000 & 0.000000 \\ .20 & 434 & .000001 & .000001 \\ .30 & 263 & .000002 & .000003 \\ .40 & 257 & .000005 & .000008 \\ .50 & 189 & .000006 & .000014 \\ .60 & 131 & .000008 & .000022 \\ .70 & 111 & .000010 & .000032 \\ .80 & 81 & .000011 & .000044 \\ .90 & 50 & .000010 & .000054 \\ 1.00 & 41 & .000011 & .000065 \\ 1.25 & 63 & .000034 & .000098 \\ 1.50 & 36 & .000033 & .000132 \\ 1.75 & 42 & .000062 & .000193 \\ 2.00 & 26 & .000057 & .000250 \\ 2.25 & 13 & .000041 & .000291 \\ 2.50 & 14 & .000060 & .000351 \\ 2.75 & 14 & .000080 & .000430 \\ 3.00 & 13 & .000096 & .000526 \\ 4.00 & 18 & .000315 & .000842 \\ 5.00 & 12 & .000411 & .001252 \\ 6.00 & 7 & .000414 & .001666 \\ 7.00 & 5 & .000470 & .002136 \\ 8.00 & 2 & .000280 & .002416 \\ 9.00 & 0 & .000000 & .002416 \\ 10.00 & 1 & .000274 & .002690\end{array}$


TABLE 3.10

PARTICLE SIZE DISTRIBUTION, TRANSIT CAPSULE T-35

Impact velocity: $325 \mathrm{fps} \quad$ Impact angle: $22.5^{\circ}$ Impact temperature: $2400^{\circ} \mathrm{F}$

\begin{tabular}{|c|c|c|}
\hline $\begin{array}{l}\text { Screen Size } \\
\text { Microns }\end{array}$ & $\begin{array}{l}\text { Weight } \\
\text { Fraction }\end{array}$ & $\begin{array}{l}\text { Accumulated Weight } \\
\text { Fraction }\end{array}$ \\
\hline 2000 & 0.87804 & 0.87804 \\
\hline 841 & .08021 & .95825 \\
\hline 420 & .01889 & .97713 \\
\hline 177 & .00859 & .98572 \\
\hline 125 & .00219 & .98791 \\
\hline 74 & .00320 & .99112 \\
\hline 44 & .00231 & .99343 \\
\hline 30 & .00163 & . 99506 \\
\hline 20 & .00125 & .99631 \\
\hline 10 & .00190 & .99821 \\
\hline-10 & .00179 & 1.00000 \\
\hline
\end{tabular}

Two velocities were considered, $150 \mathrm{fps}$ for the launch abort accident and 325 fps for the other accidents. All impact tests were run at $325 \mathrm{fps}$, allowing the particle size distributions observed to be used directly for all accidents except the

TABLE 3. 11

\section{SUB-SIEVE SIZE PARTICLE DISTRIBUTION, TRANSIT CAPSULE T-35}

Impact velocity: 325 fps Impact temperature: $2400^{\circ} \mathrm{F}$

Maximum Size in Ranze. Microns Number

0.10

.20

.30

.40

.50

.60

.70

.80

.90

1.00

1.25

1. 50

1.75

2. 00

2. 25

2. 50

2. 75

3.00

4.00

5. 00

6.00

7. 00

8. 00

9.00

10. 00
Weight Accumulated Fraction Weight Fraction
0.000000
0.000000

.000000

.000000

.000001

.000001

.000001

.000001

.000002

.000001

.000002

.000005

.000006

.000005

.000009

.000009

.000012

.000010

.000024

.000107

.000165

.000181

.000378

.000383

.000225

.000264
.000000

.000000

.000001

.000002

.000003

.000004

.000006

.000007

.000009

.000014

.000020

.000024

.000033

.000042

.000053

.000064

.000087

.000194

.000360

.000540

.000918

.001301

.001526

.001790

launch abort accident. For the latter the characteristic impact velocity chosen was $150 \mathrm{fps}$ and the characteristic impact attitude was end-on. The particle size distribution for these conditions was obtained by multiplying the distribution of $\mathrm{P}-10$ by $(150 / 325)^{2}$ and is given in Tables 3.12 and 3.13 .

The impact fines data were obtained at $1316^{\circ} \mathrm{C}\left(2400^{\circ} \mathrm{F}\right)$ for the capsule tests and at $454^{\circ} \mathrm{C}$ $\left(850^{\circ} \mathrm{F}\right)$ for the bare fuel tests, and was assumed, as indicated above, that the correlations determined would apply to the whole range.between these temperatures.

The fuel response to impact also depends on the hardness of the impact surface. For the purpose of calculating source terms, two impact surfaces, one hard and the other soft, were considered. Impact of the capsule on the hard surface was assumed to produce a particle size distribution like that of sample P- 10 (Tables 3.8 and 3.9) or T-35 (Tables 3.10 and 3.11 ), whereas impact on a soft surface was assumed to produce a particle size distribution like that of sample P-24 (Tables 3.4 and 3.5 ).

In the event that the PMC fuel should escape from the capsule prior to ground impact, the released fuel would impact at approximately $125 \mathrm{fps}$, the free fall velocity of a PMC disk. In that case, the particle size distribution would be as shown in Table 3. 14.

TABLE 3.12

CALCULATED PAR TICLE SIZE DISTRIBUTION FOR AN END-ON PIONEER CAPSULE IMPACT ON GRANITE AT 150 fps

Size

Microns

2000 .

841

420

177

125

74

44

30

20

10

$<10$
Weight

Fraction

0. 97968

.01302

.00298

.00132

.00032

.00056

.00043

.00047

.00029

.00036

.00057
Accumulated Weight Fraction

0. 97968

.99270

.99568

.99700

.99732

.99788

.99831

.99878

.99907

.99943

1. 00000 
TABLE 3.13

CALCLLATED SUB-SIEVE SIZE PARTICLE DISTRIBUTION FOR AN END-ON PIONEER CA PSULE IMPACT ON GRANITE AT 150 fpS

Maximum Size in

Weighe Accumulated

Rance. Microns Number Fraction Weight Fraction

$\begin{array}{rrrr}0.10 & 525 & 0.000000 & 0.000000 \\ .20 & 434 & .000000 & .000000 \\ .30 & 263 & .000000 & .000001 \\ .40 & 257 & .000001 & .000002 \\ .50 & 189 & .000001 & .000003 \\ .60 & 131 & .000002 & .000005 \\ .70 & 111 & .000002 & .000007 \\ .80 & 81 & .000002 & .000009 \\ .90 & 50 & .000002 & .000011 \\ 1.00 & 41 & .000002 & .000014 \\ 1.25 & 63 & .000007 & .000021 \\ 1.50 & 36 & .000007 & .000028 \\ 1.75 & 42 & .000013 & .000041 \\ 2.00 & 26 & .000012 & .000053 \\ 2.25 & 13 & .000009 & .000062 \\ 2.50 & 14 & .000013 & .000075 \\ 2.75 & 14 & .000017 & .000092 \\ 3.00 & 13 & .000020 & .000112 \\ 4.00 & 18 & .000067 & .000179 \\ 5.00 & 12 & .000088 & .000267 \\ 6.00 & 7 & .000088 & .000355 \\ 7.00 & 5 & .000100 & .000455 \\ 8.00 & 2 & .000060 & .000515 \\ 9.00 & 0 & .000000 & .000515 \\ 10.00 & 1 & .000058 & .000573\end{array}$

TA BLE 3.14

CALCULATED PARTICLE SIZE DISTRIBLTION FOR BARE PMC IMPACTED ON A HARD SURFACE AT 125 fps

\begin{tabular}{rcc}
$\begin{array}{c}\text { Size } \\
\text { Microns }\end{array}$ & $\begin{array}{c}\text { Weight } \\
\text { Eraction }\end{array}$ & $\begin{array}{c}\text { Accumulated } \\
\text { Weight Fraction }\end{array}$ \\
2000 & 0.89904 & 0.89904 \\
841 & .03782 & .93686 \\
420 & .02127 & .95813 \\
177 & .01386 & .97199 \\
125 & .00242 & .97441 \\
74 & .00340 & .97781 \\
44 & .00470 & .98251 \\
30 & .00745 & .98996 \\
20 & .00406 & .99402 \\
10 & .00345 & .99747 \\
$<10$ & .00253 & 1.00000 \\
54 & .00494 & \\
\hline
\end{tabular}

be broken into fines on impact, even though surrounded by molybdenum. The quantity of additional fines available was determined by taking the particles $>10 \mathrm{um}$ from an impacted and sized PMC sample, oxidizing them in Flowing air for 10 days at $620^{\circ} \mathrm{C}$ (the calculated post-impact temperature), and sizing them again. The results showed that 35 percent of the residual was still larger than the ceramic shard size, so the oxidation was assumed to be 65 percent complete. The weight fraction $54 \mathrm{um}$ in the residue was calculated to be 0.001 and the total frastion possible, on complete oxidation, was calculated to be $\mathbf{0 . 0 0 1 5 5}$. This latter term was used for source term calculations.

\subsection{FUEL RELEASE ASSTMPTIONS \\ 4.1 Mechanical Events}

No data exist for the quantity of PMC released through a hole in a capsule, so it was assumed that all the fuel behind a hole would be released when the hole is formed, with the provisos that no piece larger than the hole could pass through it, and the hole would be considered empty for subsequent events. The size distribution of the fuel in the capsule was assumed to be uniform throughout the capsule. It was also assumed that every hole formed would be as large as the largest hole observed in the test program, $2.5 \mathrm{~cm}^{2}$, and large enough to pass a $0.6-\mathrm{cm}$ dia piece. A hole this size accounts for 0.037 of the Pioneer capsule's longitudinal cross-sectional area. In addition, it was assumed that 10 percent of the particles $\leq 4$ um present would pass out through the hole.

The total release for each event causing a hole is:

Fuel Release $=r 0.037 \times$ W. F. $\leq 6000 \mu \mathrm{m}+0.063$ W. F. $\leq 10 \mu \mathrm{m} 7 \times 20,200 \mathrm{Ci}$

3. 3. 2. 4 Post-Impact Oxidation. Once the fuel within the capsule has been exposed to air, its molybdenum component will oxidize, freeing the $\mathrm{PuO}_{2}$ particles. Some of these particles will
The biologically important particle size is $\sim 4 \mu \mathrm{m}$ because particles this size and smaller can become entrained in the lower lung. In order to enter the lung. however, they must first be in the breathing zone. Not all particles released from 
the capsule will be immediately suspended in the breathing zone. Boring ${ }^{(9)}$ has estimated that the fraction $\leq 4 \mathrm{um}$ immediately suspended would range from $10^{-2}$ for low velocity events in still air to $10^{-1}$ for high velocity events in turbulent air. Still air conditions would not be expected to be present in the case of accidents near the launch area, but they might exist in the reentry accident case. In all cases considered here, however, the prompt resuspension factor was assumed to be $10^{-1}$. Thus the prompt release of respirable particles to the breathing zone would be given by:

Respirable Source Term $=[0.1 \times 0.1 \times$ W.F. $\leq 4 \mu \mathrm{m}] 20,200 \mathrm{Ci}$
TABLE 4.1

VAPORIZATION FACTORS FOR $\mathrm{PuO}_{2}$ IN AN ATLAS-CENTAUR FIREBALL

\begin{tabular}{c} 
Original Particle \\
Diameter, Microns \\
\hline 6000 \\
2000 \\
841 \\
420 \\
177 \\
125 \\
74 \\
44 \\
$\leq 30$
\end{tabular}

\begin{tabular}{c}
$\begin{array}{c}\text { Weight Fraction } \\
\text { Vaporized }\end{array}$ \\
\hline 0.0007 \\
.0007 \\
.0041 \\
.016 \\
.092 \\
.185 \\
.528 \\
.957 \\
1.000
\end{tabular}

\subsection{Thermal Events}

4.2.1 Fireball. The fireball itself cannot cause a fuel release, but, if fuel is released by a mechanical event, the fireball can then contribute to the source term by vaporizing some of the mechanically released fuel. The amount vaporized depends on the size of the fuel particles in the fireball and can be calculated using Williams' model. (10) Specifically, this model was derived from $\mathrm{PuO}_{2}$ spheres $100 \mu \mathrm{m}$ dia, but it has been extended to other sizes by Boring. (11) The weight fractions vaporized for the various sizes are given in Table
The quantity vaporized is the product of the PMC area exposed, the time, and the vaporization rate at the flame temperature. In vacuum, the vaporization rate at the $2500^{\circ} \mathrm{K}$ flame temperature is $1.35 \times 10^{-3} \mathrm{~g} / \mathrm{cm}^{2}-\sec ^{(12)}$ and in air it is 0.02 of this $^{(13)}$ or $0.27 \times 10^{-4} \mathrm{~g} / \mathrm{cm}^{2}$-sec. The specific activity of $\mathrm{PMC}$ is $11.7 \mathrm{Ci} / \mathrm{g}$, so the vaporization rate is $0.32 \times 10^{-3} \mathrm{Ci} / \mathrm{cm}^{2}$-sec.

In the case of a capsule in contact with a piece of burning solid propellant the a rea exposed is equal to the area of the hole in the capsule and the vapor released would be given by:

$$
\text { Vapor Source Term }=0.31 \times 10^{-3} \times \text { B. T. } \times A_{\mathrm{Hole}} \mathrm{Ci}
$$

4.1. Thus, the total quantity vaporized would be the sum of the products of the weight fraction released and the weight fraction vaporized for each size fraction, multiplied by the total activity in the capsule.
If no holes are present in the capsule, it is assumed that a $2.4 \mathrm{~cm}^{2}$ hole forms after $45 \mathrm{sec}$ and that the time available for vaporization through this hole is the burning time less $45 \mathrm{sec}$. Thus, the release would be given by:

$$
\begin{aligned}
\text { Vapor Source Term } & =0.31 \times 10^{-3} \mathrm{Ci} / \mathrm{cm}^{2}-\sec (\text { B. T. }-45 \mathrm{sec}) \times 2.42 \mathrm{cr}^{2} \\
& \left.=0.75 \times 10^{-3} \text { (B. T. }-45 \mathrm{sec}\right) \mathrm{Ci}
\end{aligned}
$$

\subsubsection{Solid Propellant Residual Fire. The} fuel release from the solid propellant fire is in the form of vapor from pieces of PMC that come in contact with burning pieces of the solid propellant.

\subsection{FUEL CONDITION}

The particle size distribution of the PMC fuel in a capsule depends on the mechanical events to which it has been exposed and is different for 
each possible accident case. Obviously, every capsule would contain the vibration fines, but not all would be subjected to a fragment impact or a hard surface impact. The particular size distribution to be expected in each of the general accident cases is discussed below.

\section{1 Launch Pad Abort}

In this accident, the only fuel release as a result of the mechanical environment would be caused by impact on sharp steel. There are, the refore, only two size distributions to consider. One results from vibration $(P-23, P-24)$ and 150 fps impact $\Gamma$ the size distribution of P-10 multiplied by $\left.(150 / 325)^{2}\right]$, and the other results from vibration, fragment impact (P-13), and 150 fps capsule impact. These distributions are shown in Figure 5.1 and listed in Table 5.1. The particle size data were obtained only up to $2000 \mu \mathrm{m}$, so the fractions present of other, larger, sizes were determined by extrapolation, assuming on asymptotic approach to the spherical equivalent diameter of a PMC fuel disk.

\subsection{High Velocity Accident}

In this case, it was assumed that fuel would be released from the capsule by the impact and the fragment impact. The blast overpressure would cause all the fuel released from the capsule to be blown into the air where a portion of it would be vaporized by the fireball. Those fuel fragments larger than $420 \mu \mathrm{m}$ would be in the fireball until the start of lift-off, $1.5 \mathrm{sec}$, while the smaller particles would be entrained in the fireball for its effective lifetime, $6 \mathrm{sec}$.

The particle size distribution of the fuel in the capsule would be that resulting either from vibration (P-23, $P-24)$ and 325 fps impact ( -10$)$ or from vibration, impact, and fragment impact (P-13). These size distributions are shown in Figure 5.2 and listed in Table 5. 2.

\section{3 Air Destruct Accident}

In this accident it was assumed that fuel release would occur only on terminal impact onto a hard

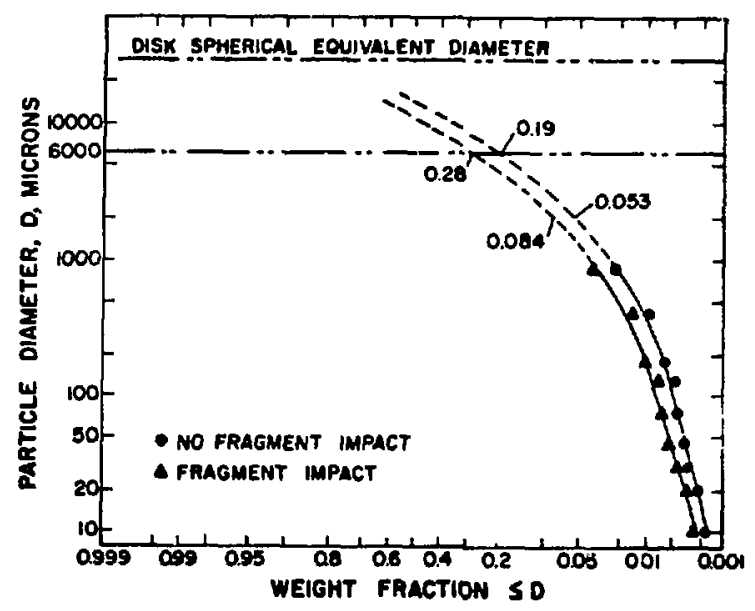

Fig. 5.1. Fuel size distribution, launch pad abort accident.

surface. Again, there are two possible particle size distributions in the PMC fuel, one resulting from vibration $(\mathrm{P}-23, \mathrm{P}-24)$ and 325 fps free fall impact ( $\mathrm{T}-35)$ and the other from vibration, fragment impact (P-13), and 325 fps free fall impact. These size distributions are shown in Figure 5. 3 and listed in Table 5. 3 .

$5.4 \quad$ Reentry

5.4.1 Capsule Intact. On terminal impact after reentry, fuel release will occur only on

TABI.E 5.1

FUEL SIZE DISTRIBUTION--LAUNCH PAD ABORT Weight Fraction $\leq \mathrm{D}$

\begin{tabular}{ccc}
$\begin{array}{ccc}\text { Size, D } \\
\text { Microns }\end{array}$ & $\begin{array}{c}\text { No Fragment } \\
\text { Impact }\end{array}$ & $\begin{array}{c}\text { Fragment } \\
\text { Impact }\end{array}$ \\
\cline { 2 - 2 } 6000 & $0.19^{\mathrm{a}}$ & $0.28^{\mathrm{a}}$ \\
2000 & $.053^{\mathrm{a}}$ & $.084^{\mathrm{a}}$ \\
841 & .02254 & .03832 \\
420 & .00944 & .01585 \\
177 & .00632 & .01059 \\
125 & .00485 & .00768 \\
74 & .00446 & .00691 \\
44 & .00375 & .00567 \\
30 & .00308 & .00442 \\
20 & .00240 & .00344 \\
10 & .00185 & .00259 \\
$<10$ & .00111 & .00151 \\
54 & .000248 & .000310
\end{tabular}

a Determined by extrapolation, see Fig. 5. 1 . 


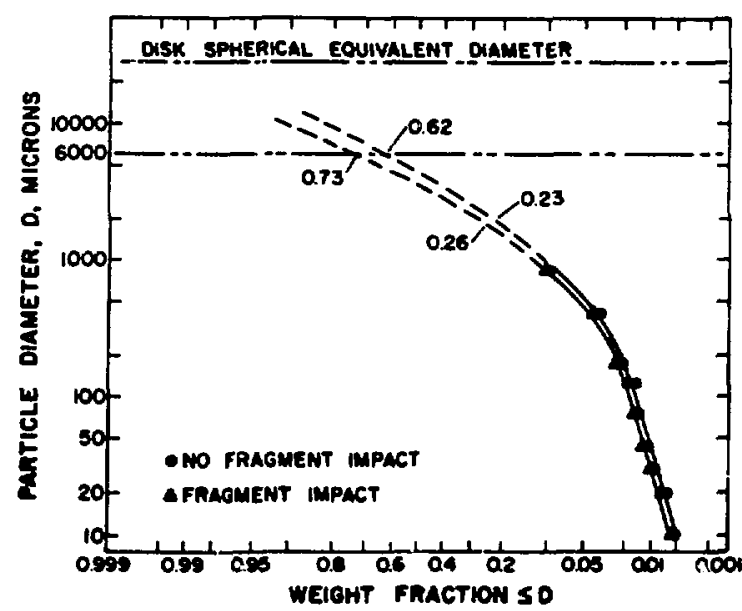

Fig. 5.2. Fuel size distributions, high velocity impact accident.

impact with a hard surface. There are, however, two fuel particle size distributions to consider. which depend on the age of the fuel. The particle size distribution will be determined by pre-launch vibration (P-23, P-24), launch vibration (P-23, P24), and $325 \mathrm{fps}$ free fall impact (T-35 or $1.5 \times \mathrm{T}$ 35). These size distributions are given in Figure 5. 4 and listed in Table 5.4.

5.4.2 Capsule Failure. If the reentry conditions are such that the heat shield fails, the

TABL.E 5.2

\begin{tabular}{|c|c|c|}
\hline \multirow[b]{2}{*}{$\begin{array}{l}\text { Size D. } \\
\text { Microns }\end{array}$} & \multicolumn{2}{|c|}{$\begin{array}{l}\text { ACCIDENT } \\
\text { Weight Fraction } \leq \mathrm{D}\end{array}$} \\
\hline & $\begin{array}{l}\text { No Fregment } \\
\text { Impact }\end{array}$ & $\begin{array}{r}\text { Fragment } \\
\text { Impact }\end{array}$ \\
\hline 6000 & $0.62^{a}$ & $0.73^{8}$ \\
\hline 2000 & $.23^{a}$ & $.26^{a}$ \\
\hline 841 & .09761 & .11339 \\
\hline 420 & .03643 & .04284 \\
\hline 177 & .02230 & .02657 \\
\hline 125 & 01593 & .01876 \\
\hline 74 & .01438 & .01683 \\
\hline 44 & .01159 & .01351 \\
\hline 30 & .00933 & .01067 \\
\hline 20 & .00693 & .00797 \\
\hline 10 & .00529 & .00603 \\
\hline $\begin{array}{l}<10 \\
\leqslant 4\end{array}$ & .00323 & $\begin{array}{l}.00363 \\
.000973\end{array}$ \\
\hline
\end{tabular}

apetermined by extrapolation, see Fig. 5.2.

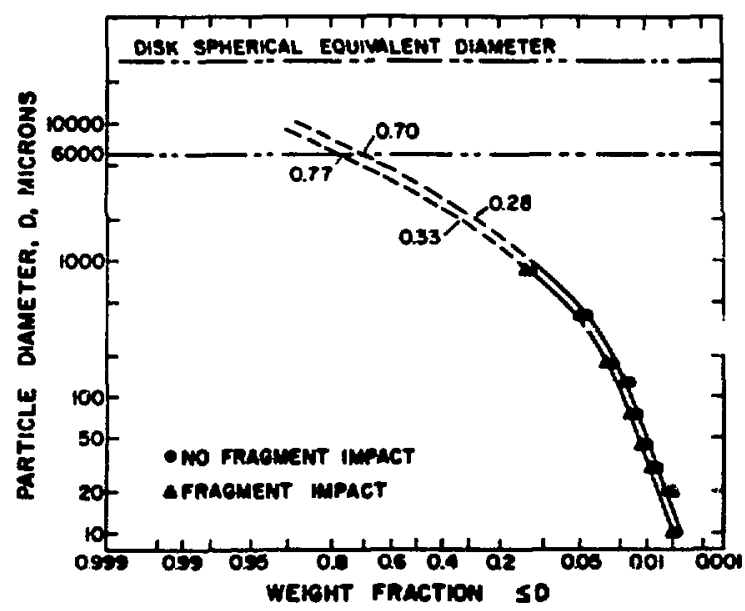

Fig. 5. 3. Fuel size distributions, air destruct accident.

cepsule will also fail and release the fuel disks to reenter bare. During thic reentry, some of the fuel will vaporize and the remainder will impact on the ground. The size distribution of the fuel impacting the ground is given in Table 3.14 .

\subsection{SOURCE TERMS}

The possible source terms resulting from the various accidents considered here will now be described.

TABLE $\mathbf{3} .3$

FUEL SIZE DISTRIBUTION- -AIR DESTRUCT ACCIDENT

\begin{tabular}{l} 
Size D, \\
Microns \\
\hline 6000 \\
2000 \\
841 \\
420 \\
177 \\
125 \\
74 \\
44 \\
30 \\
20 \\
10 \\
$<10$ \\
$\leq 4$
\end{tabular}

$$
\text { Weight Fraction } \leq \mathrm{D}
$$

No Fragment Frogment

\begin{tabular}{l} 
Impact \\
\hline $0.70 a$ \\
$.28^{a}$ \\
.12418 \\
.04389 \\
.02486 \\
.01612 \\
.01386 \\
.01051 \\
.00796 \\
.00612 \\
.00461 \\
.00233 \\
.000263
\end{tabular}

Impect
0.77
.33
.13996
.05030
.02913
.01895
.01631
.01243
.00030
.00716
.00535
.00273
.000325

a Determined by extrapolation, see Fig. 5.3. 


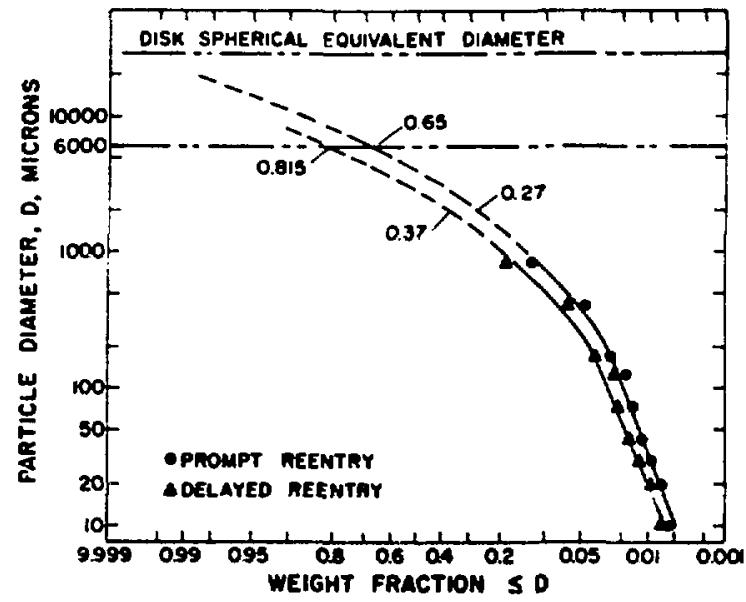

5. 4. Fuel size distribution. intact capsule reentry.

\subsection{Launch Pad Abort}

The size distributions present in the capsule as a result of a launch pad accident are shown in Figure 5. 1 and listed in Table 5.1. The total release from a capsule that fails on terminal impaci would be, from E.q. (4.1):

No fragment impact:

$[0.03\rceil \times 0.19+0.063 \times 0.00111] 20,200 \mathrm{Ci}=3+3 \mathrm{Ci}$

Fragment impact:

$[0.03 i \times 0.28 \div 0.63 \times 0.00151] 20,200 \mathrm{Ci}=211 \mathrm{Ci}$

TABLE $\mathbf{5} 4$

FLEL SIZE DISTRIBLTION-REENTRY IMPACT

\begin{tabular}{|c|c|c|}
\hline $\begin{array}{l}\text { Size, D, } \\
\text { Mic rons }\end{array}$ & $\begin{array}{l}\text { Prompt } \\
\text { Reentry }\end{array}$ & $\begin{array}{l}\text { Delayed } \\
\text { Reentry } \\
\end{array}$ \\
\hline $\begin{array}{l}6000 \\
2000\end{array}$ & $0.65^{\mathrm{a}}$ & $0.815^{a}$ \\
\hline 841 & 12640 & $187+2$ \\
\hline 420 & .04603 & .06694 \\
\hline 177 & .02686 & .03832 \\
\hline 125 & .01797 & .02513 \\
\hline 77 & .01564 & .02170 \\
\hline $4 t$ & .01214 & .01660 \\
\hline 30 & .00935 & .01265 \\
\hline 20 & .00730 & .00978 \\
\hline 10 & .00553 & .00738 \\
\hline$=1$ & .00287 & .00377 \\
\hline-4 & .000332 & .010429 \\
\hline
\end{tabular}

${ }^{a}$ Determined by sxtrapolation, see Fig. 5.4.
The yrompt dispersion of respirable sized particles, $\$ 4 \mu \mathrm{m}$ dia, would be, using Eq. (4.2) No fragment impact:

ro. $1 \times 0.1 \times 0.000248 \div 20,200 \mathrm{Ci}=0.05 \mathrm{Ci}$

Fragment impact:

r0.1 $10.1 \times 0.00031 ; 10,200 \mathrm{Ci}-0.06 \mathrm{Ci}$

In the event that the capsule should land on a piece of solid propellant, the additional source term for the vapor formed would be determined from Eqs. (4.3) and (4.4). The vapor would be released near ground level.

\section{2 High Velocity Accident}

The size distributions present in the capsule for this accident are given in Fig. 5.2 and Table 5.2. The total activity released on failure would be:

1) impact failure with no fragment impact. $\$ 67 \mathrm{Ci} ; 2)$ impact failure with fragment impact, $550 \mathrm{Ci} ; 3)$ impact and fragment failures, $1100 \mathrm{Ci}$. These quantities would be released to the fireball, and the resulting vapor source terms would be, using the releases above and the vaporization terms shown in Table $4.1,14.6 \mathrm{Ci}, 16.9$

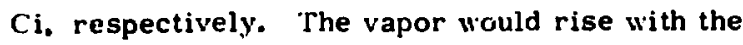
fireball and be dispersed at the fireball's characteristic height.

An additional, near ground, vapor source term would be present if any PMC material released from the capsule but not consumed by the fireball should come into contact with burning solid propellant. The quantity vaporized would then be given by Eq. (4, 3), and the area would be the exposed area of the PMC.

6.3 Air Destruct Accident

The size distribution of the fuel in a capsule at the time of failure is shown in Figure 5.3 and Taile 5.3. The release on terminal impact with a hard surface would be $526 \mathrm{Ci}$ if no fragment impact occurred, or $579 \mathrm{Ci}$ if a fragment did impact the capsule. The prompt suspension of respirable fines would be $0.05 \mathrm{Ci}$ and $0.07 \mathrm{Ci}$, respectively. 
6. 4 Reentry

6. 4. 1 Capsule Intact. The size distribution of the fuel would be one or the other of those given in Figure 5.4 and listed in Table 5.4, depending $\mathrm{cn}$ the age of the fuel. The release, through the single hole postulated to form on impact with a hard surface, would be $489 \mathrm{Ci}$ or $609 \mathrm{Ci}$. The prompt suspension should be $0.07 \mathrm{Ci}$ or $0.09 \mathrm{Ci}$.

6. 4. 2 Capsule failure. Should the capsule fail on reentry, some portion of it would vaporize and the remainder would impact the ground. The resulting particle size distribution is given in Table 3.14. The total near ground release would be the product of the fraction remaining after reentry and the total capsule activity, $20,200 \mathrm{Cl}$. The fraction vaporized was calculated to be 0.16 ( $^{(3)}$ So, 3250 Ci would be released as vapor in the upper atmosphere and 16,950 $\mathrm{Ci}$ would impact the ground. The prompt suspension of respirable particles would amount to $0.56 \mathrm{Ci}$ if the tuel were relatively fresh or $0.73 \mathrm{Ci}$ if it were aged.

\section{5 Post-Impact Oxidation}

After oxidation of the capsule and the molybdenum component of the fuel, the fines present will be available for dispersion. The total weight fraction of fines present would be 0.00188 for prompt impacts and 0.00275 for delayed impacts, $38 \mathrm{Ci}$ and $56 \mathrm{Ci}$, respectively. The time dependent distribution of the fines thus exposed has been calculated by Fuquay. $(2,14)$

\section{0 SUMMARY}

The source terms calculated for each accident are summarized in Table 7.1. These terms were calculated using the assumptions described above. As previously indicated, the basic assumption is that the fueled capsules will respond in the same manner as did those used in the safety test series. If this assumption is correct, the source terms calculated here are realistic, but conservative. estimates of those to be expected for fueled cepsules exposed to accident enviranments.

\section{ACKNOWLEDGMENTS}

Dorothy Garinger aided in calculating the source terms and in preparing and editing this report, and the particle size data were obtained largely through the efforts of Arthur Herrera, Richard Buteau, and Dana Douglass.

\section{REFERENCES}

1. Teledyne-Isotopes, Nuclear System Division, "SNAP 19/Pioneer F Safety Analysis Report, Vol. I, " Report No. INSD-2873-42-1. June, 1971.

2. T. B. Kerr, G. P. Dix, M. M. MacWilliams, "Pioneer F Nuclear Safety Evaluation Report (Confidential)", Report No. SNSD-LA-1, December 11, 1971 .

3. Teledyne-Isotopes, Nuclear Systems Division, "Safety Test Program Summary SNAP 19, Ploneer Heat Source Safety Program". Report No. INSD-2873-71, July, 1971.

4. TRW Systems group. "Transit RTG Final Safety Analysis Report, Vol. III, "Report No. TRW (A)-11464-0493, March 1, 1971.

5. J. R. Morgan and S. E. Bronisz, "Oxidation Behavior of Transit Capsule $T-47$, " to be published.

6. R. N. R. Mulford, private communication.

7. S. E. Bronisz, personal observation during the postmortem examinations of test capsules PF-7 and PF -9 . 8. S. E. Bronisz, "The Particle Sizing of ${ }^{238} \mathrm{PuO}_{2}$
Containing Radioisotopic Heat Source Fuels," to be published.

9. A. M. Boring, private communication, Nov., 1971.

10. D. C. Williams, "Vaporization of $\mathrm{PuO}_{2}$ in a Launch Pad Fireball". Report No. SC-RR-68441, August, 1968.

11. A. M. Boring. "Vaporization Calculations for $P-10$ and $P-15$ " LASL internal report No. CMB-5-C-178, Nov. 4, 1971.

12. Los Alamos Scientific Laboratory, "PMC Fuel Manual". LASL internal report No. CMB-5-C101, Avgust 27, 1971.

13. J. W. Ward, "Calculation of the Escape of Pubearing Species from a MHW Unit", LASL 
interual report No. CMB-5-C-53, Feb. 25 , 1971.
14. J. J. Fuquay, "The Post-Impact Protracted Oxidation SoL:ce Term-Snap/Transit, "BNWL interna! repont, urnumbered, Oct. , 1971.

TAELE 7,1

SOURCE TERM SUMMARY FOR A PIONEER ATG EXPOSED TO ACCIDENT ENVIRONMENTS LEAUNG TO CAYSULE EAILURE

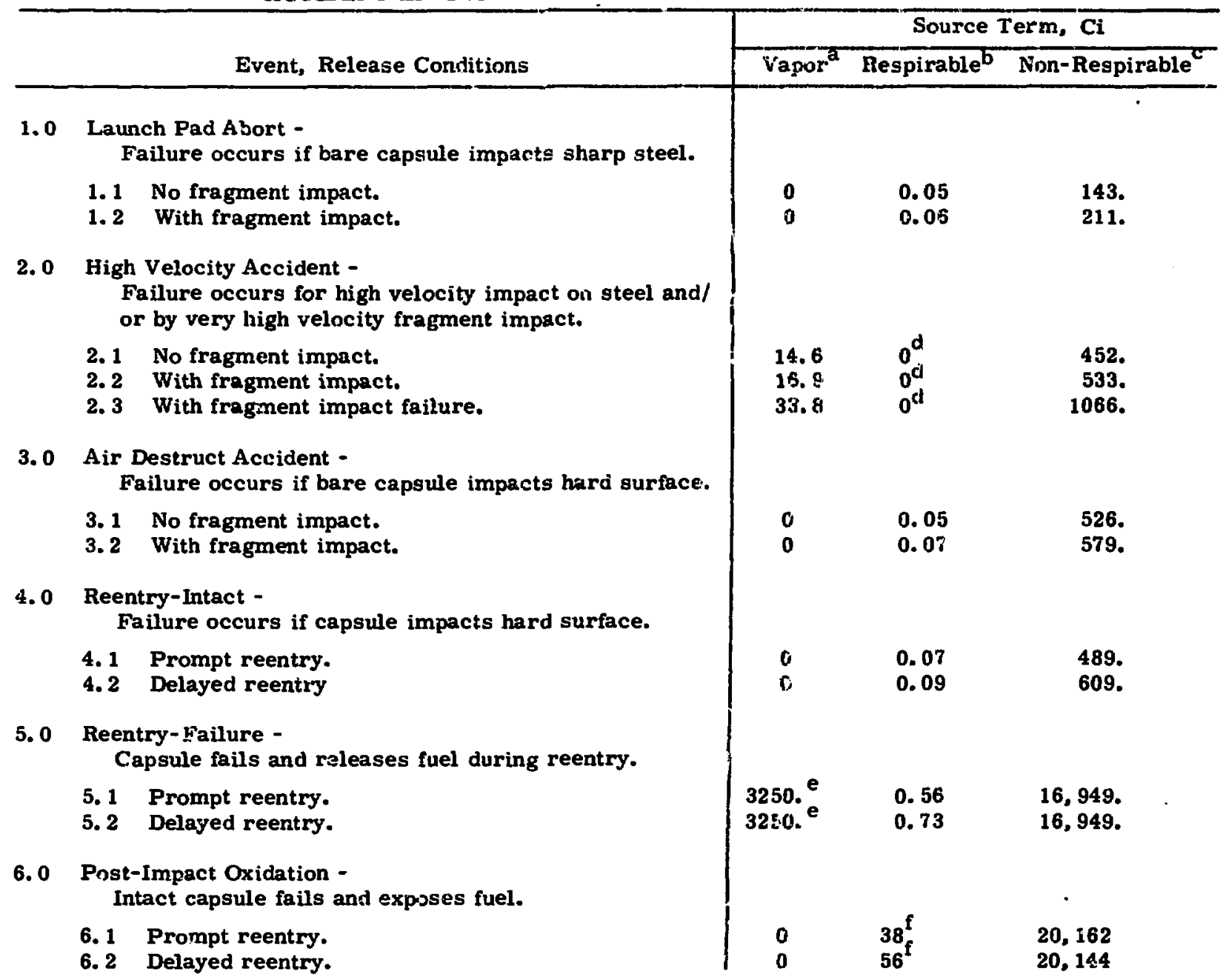

The vapor source term refers to that material vaporized in a firebell. An additional vapor term due to direct contact with burning solid propellant may be present. Its magnitude would be given by Eq. (4. 3) or (4.4).

b The respirable source term is that quantity of fuel 54 um diameter and suspended in the atmosphere promptly after a mechanical event.

c The non-respirable source term is that quantity of fuel $>4 \mathrm{um} t \mathrm{tat}$ escapes the capsule and those particles $\leq 4 \mathrm{~mm}$ that are not promptly suspended in the atmosphere.

din this accident a freball was assumed to be inevitable, so all the tines released would be vaporized.

This vapor would be released in the upper atmosphere during reentry. The quantity was estimated in Ref. 3.

This respirable source term is the total $\leqslant 4 \mathrm{\mu m}$ fines available twom an impacted and completely oxidized capsule. The release occurs over a period of weeks. 